\title{
Investigating Attitudes towards Refugee Students based on Several Variables: Revised Version of Refugee Student Attitude Scale*
}

\author{
Ragıp TERZi $^{* *}$ Ahmet GöÇEN ${ }^{* * *}$ Bilal ALTUN ${ }^{* * * *}$
}

\begin{abstract}
The immigration movement sometimes causes a sudden demographic complexity for countries and then leads to the development and implementation of urgent public policies. The most important one of urgent policy areas in the long term is education. In countries, especially in case of foreign migration, international aid organizations provide food, shelter, heating, and so on at the first place, and then aim to ensure linguistic, cultural, and social cohesion of migrants. At this stage, the contribution of hosting teachers and school administrators to attitudes towards migrants and inclusive education policies is a key to the efficient functioning of the process. In this study, attitudes towards refugee students of teachers in Sanliurfa, one of Turkey's most populated-refugee cities, is investigated based on several variables. For the purpose, Refugee Student Attitude Scale (RSAS), developed by Sağlam and Kanbur (2017), was updated via EFA and CFA analyzes and then analyzed by MANOVA. It was found that attitudes of young female teachers towards "communication" and "adaptation" were higher than male teachers; in contrast, male teachers teaching for long years were better in their "communication" and "competency" attitudes than female teachers. Furthermore, teachers with many years of teaching experience who have refugee students in their class are higher in "communication" and "adaptation" attitudes.
\end{abstract}

Keywords: Migration Policy, Teacher Attitudes, Refugee Education, Inclusive Education.

\footnotetext{
* This study was supported by the European Union Education and Youth Programs Center Erasmus+ Project, entitled "The Right of Education of Refugees and A Little Empathy" and numbered 2018-1-TR01-KA229060961_1 of Şanlıurfa Hattat Behçet Arabi Imam Hatip Secondary School. The European Commission and the National Agency of Turkey can not be held responsible for the opinions expressed in this study.

** Orcid id: https://orcid.org/0000-0003-3976-5054 Asst. Prof. Dr., Harran University, School of Education, terziragip@harran.edu.tr

${ }_{* * *}$ Orcid id: https://orcid.org/0000-0002-9376-2084, Asst. Prof. Dr., Harran University, School of Education, ahmetgocen35@gmail.com

${ }_{* * * *}$ Orcid id: https://orcid.org/0000-0002-3535-9182, Teacher, Ministry of National Education, bilalaltun063@gmail.com
} 


\section{INTRODUCTION}

Migration generally involves the physical displacement of societies or groups of people for economic, cultural and political reasons. Migration causes significant changes in the lives of migrants within the scope of social, cultural, and economic impacts. If the migration process is not managed effectively in terms of its stakeholders and related elements, it may have negative effects not only on the migrants, but also on the order and accepted structure of the migrated place. Migrations can be categorized as "obligatory and voluntary" according to the reasons of those who migrate, "permanent and temporary" according to the length of stay at the place of migration, and "internal and external" according to the direction of migration (Çatalbaş \& Yarar, 2015). Although the concepts of migrant or immigrant are generally used in the definition of migration, the concept of refugee used in this study is also important for a better understanding of the issue. According to the 1951 Convention Relating to the Status of Refugees (1951), refugee is the person who can not or does not want to return his/her homeland due to fear of violence and persecution stemming from his/her race, religion, nationality, belonging to a certain social group or political attitude.

Since the declaration of the Republic, migration movements in Turkey in general have occured in the form of internal migration and urbanization apart from population exchange among the countries. Carrying out open-door policy with the emergence of conflict in Syria, Turkey faced a migration flow with 3.5 million people into the country, and in some provinces like Şanlıurfa and İstanbul, about half a million Syrian citizens began to live. This rapidly developing situation has affected the economic structure of the migrated region and caused major problems in school capacities and management of educational resources.

When migrant groups are evaluated, the most affected members are the children at the age of schooling. For children and families who experience forced migration, the loss of home and the departure from their own country means the destruction of their dreams; thus, the migration process requires people to forget the past and get used to their new life (Miserez-Willday, 1988). The education of people who leave their homeland and take refuge in another region or country upon war or internal conflicts becomes more complicated (Yavuz \& Mizrak, 2016). On the other hand, under prospective or urgent action-based educational policies, education can serve as a compensatory tool for refugees by reducing uncertainty and increasing self esteem. Aside that, community support, teacher qualifications, educational tools and management structure can systemically affect refugees' educational attainments (Alpaydın, 2017). It is important to note that the education provided to refugees should be high quality and have meaningful value for them, otherwise the desired attainments will not be achieved (DrydenPeterson, 2011).

For policymakers, studies on attitudes, problems and views of students and teachers in the literature concerning migration may contribute significantly to the implementations aimed at reducing the negative impact of migration in education. Çoşkun and Emin 
(2016) stated that Syrian students experience adaptation problems in schools and the reluctance of some administrators to register Syrian children in schools, the negative attitudes and behaviors such as rejection by teachers, students and parents, exclusion, marginalization and peer bullying in the school also make the adaptation process difficult. Kardeş and Akman (2018) at the end of their study stated that refugee children have language problems and adaptation problems. Within an effective management and policy program against the problems of refugee students, these authors suggested solutions such as increasing these children's participation in pre-school education, regulation of the class environment, increased family participation, attention to language education, and resolution of school adaptation problems through psychological and guidance services. Therefore, it is necessary for policy makers in the field of education, school administrators, teachers and parents to support refugee children for social cohesion, and bring in comprehensive inclusive education policies with the initiatives and steps taken towards the education of immigrants.

\section{Education Policies on Migration, Diversity Management, and Inclusive Education}

The problems that emerge as a result of migration cause significant effects in the immigrated society as well as families and children, which could sometimes lead to social disintegration Therefore, it is necessary for the governments hosting migration to have a strategic approach and develop an action plan within diversity management approach. The worldwide increase of refugees and asylum seekers reveals the necessity to re-examine the practices and policies of resettlement institutions in the host countries (Taylor \& Sidhu, 2012). One of the healthiest methods to reduce the negative impacts of migrations within the natural process in the host region is an inclusive education approach based on the management of differences. In this way, the attitudes and behaviors of the host country's teachers and students can be influential in the integration of refugees into the society.

It is thought that Syrian citizens will generally return to their countries by 2014; however, the fact that Syrian students are now allowed to enroll in public schools as Turkish citizens do and that they are integrated into normal education is an indication that Syrian refugees have become a continuous part of the society (Kılcan, Çepni, \& Kılınç, 2017). In 2011, Syrian citizens began to settle in Turkey as if they would no longer return to Syria, which led to different situations in Turkish education policies. Thus, the current educational structure is directed towards an inclusive education model that is more sensitive to cultural demands (Özcan, 2018). In order to strengthen inclusive education, the Ministry of National Education (MoNE) has implemented "Inclusive Education Working with Children under Temporary Protection" program with the support of Erciyes University and in cooperation with UNICEF and has provided trainings to thousands of teachers on this subject. MoNE General Directorate of Teacher Training (2018) defines the inclusive education it provides for diversity management within schools and the effective integration of refugee students: 
"The solid goal of these trainings is to contribute to the development of social justice with a human-centered approach, to ensure that the differences and characteristics of each child are included in educational activities, to eliminate discrimination against children in schools, to prevent the change and adjustment of personalities in classs, and to contribute to make each child to be seen as a valuable individual."

Düşkün (2016) states that teachers have key roles in terms of inclusive education and teacher attitudes are important for establishing an inclusive education policy. Teachers have a strong guiding effect on the adaptation of new students into the school, who are described as guests, immigrants or refugees. Therefore, in this study, it is aimed to examine the attitudes of the teachers towards refugee students in a province where Syrian refugees live densely. In this respect, two objectives were pursued in line with the related literature; a) revising the attitude scale towards refugee students b) examining teachers' attitudes towards refugee students in terms of having a refugee student in the class, gender and teaching year variables. The reason for selecting these variables is to learn if the refugee students in the teachers' class and the time spent with them affect teachers' views. It is also intended to see the role of teaching experience/teaching year and gender in the attitudes towards the refugee students. Aside that, in this study with a different sample (one of the provinces, Sanliurfa, where Syrian refugees live densely) and after a certain period, it was desired to re-examine an existing attitude scale developed on the subject. The average of teachers' attitude points towards refugee students was given. In the light of these data, policy makers will be presented with a study that they can take into consideration especially in inclusive education activities.

\section{METHOD}

This research is a quantitative study, in which, a correlational survey model was preferred because dependent and independent variables were examined in order to predict the dimensions of teachers' attitudes towards refugee students. Correlational survey model; is the research model used to determine the degree of change between two or more variables (Karasar, 2005).

\section{The Refugee Student Attitude Scale}

In this study, the Refugee Student Attitude Scale (RSAS) developed by Sağlam and Kanbur (2017) was used. This scale was initially formed from a pool of 45 items. Within the framework of construct validity, the scale was finalized with 24 items based on expert opinions and factor analysis and consisted of 3 dimensions: communication (11 items), compliance ( 9 items) and competence ( 4 items). The RSAS consists of Likert-type items that can be scored between 0 (strongly disagree) and 4 (strongly agree). The internal consistency coefficient (Cronbach's alpha) for the whole scale was .91. The reliability coefficients in terms of internal consistency regarding communication, compliance, and competency dimensions were reported as .88 , .88, and .80 , respectively. In this study, a personal information form along with the scale was added to obtain the 
demographic information of teachers. In the personal information form, there are 8 questions for the participants such as age, gender, how many years they are teachers, area, branch, number of teachers in their schools, whether or not they have refugee students in class and school.

In order to make the analyzes within the scope of this study, the data were firstly subjected to confirmatory factor analysis (CFA) and, as shown in the findings section, it was decided to revise the RSAS because the fit indices were lower than the expected value. Therefore, the data were analyzed again by using exploratory factor analysis (EFA) and then CFA to determine the extent to which the items fit better. The data collected for these two analyzes $(N=865)$ were randomly divided into two parts and the sample number of EFA was 433 and the CFA was made on 432 people. The fact that the sample size used in factor analysis is more than 10 times the number of items is consistent with the values recommended in the literature (Nunually \& Bernstein, 1978). SPSS version 22.0 (IBM Corp, 2013) was used for EFA. Principle component analysis has been used for the extraction method, which is frequently preferred as a factorization technique (Büyüköztürk, 2002). For the rotation method, Varimax Kaiser Normalization, which is one of the vertical rotation methods, was chosen. Vertical rotation is preferred because it provides convenience in interpretation (Rennie, 1997), and the purpose of selecting Varimax from vertical rotation methods is to have a multifactorial structure of RSAS (Büyüköztürk, 2002). When performing EFA analysis, the number of factors was fixed to 3 as in the original RSAS.

\section{Participants}

There are 250 institutions including private and state educational institutions (villagecenter) in Haliliye district of Şanlıurfa province. A total of 5,186 teachers work in the district. The data in this study were collected from 29 schools in Haliliye. The reason for the study is that it is one of the provinces receiving the highest number of Syrian refugee migration due to its proximity to the Syrian border and the implementation of an EU project on "Empathy for Refugee Students" in Haliliye, including the researchers of this study. The scale included in the study was notified to all schools by an official letter, but 29 schools, consisting of primary, secondary, and high schools, were able to submit the questionnaires within the given period. The reason for not being able to include all schools is that some village schools have sent the surveys late or some central schools were late in the distribution and collection of the surveys.

As shown in Table 1, among 865 teachers, 473 (55\%) female and 385 (45\%) male; 399 (46\%) were between 20-30 years old, 335 (39\%) were between 31-41 years old and 125 (15\%) were older than 41 years; 527 (61\%) were in the field of Social Science, 194 (22\%) were in the field of Science; while 803 (93\%) like their field, 36 (4\%) do not like their field; 365 (42\%) were teachers for 0-5 years, 236 (27\%) teachers for 6-11 years and 259 (30\%) teachers for 12 years and over; 8 (1\%) teachers had between 1-10 people in their schools, $49(6 \%)$ teachers had between 11-20 people in their schools, $181(21 \%)$ teachers had between $21-30$ people in their schools, $592(68 \%)$ teachers had 
31 or more teachers in their schools; 812 (94\%) teachers had refugee students in their class, while $39(5 \%)$ teachers did not have refugee students in their class; while 852 (99\%) teachers had refugee students in their school, 2 teachers did not have refugee students in their school. Since the missing data of demographic variables cannot be estimated by using other variables and do not provide information in the analyzes, they were not included in the analyzes by deleting them with listwise deletion method. However, missing data in the scale questions were estimated using the ExpectedMaximization (EM) algorithm using SPSS 22.0 version (IBM Corp, 2013). The purpose of using the EM algorithm for missing data is the EM repetitive algorithm, which first repeats missing data until it is determined that the assigned value has the highest likelihood (Maximization) by making an estimate of each individual's response to other questions (Expectation). Thus, the answer that the individual can give to the question left blank is determined according to the other answers.

Table 1.

Demographic Characteristics of Participants

\begin{tabular}{cccc}
\hline Variables & $N$ & $\%$ \\
\hline Gender & Women & 473 & 55 \\
& Men & 385 & 45 \\
\hline Age Range & $20-30$ & 399 & 46 \\
& $31-41$ & 335 & 39 \\
Area of Expertise & 41 and above & 125 & 15 \\
\hline & Social Science & 527 & 61 \\
& Science & 194 & 22 \\
\hline & Like & 803 & 93 \\
& Unlike & 36 & 4 \\
\hline Being Teachers in Years & $0-5$ & 365 & 42 \\
& $6-11$ & 236 & 27 \\
& 12 and above & 259 & 30 \\
\hline Number of Teachers & $1-10$ & 8 & 1 \\
& $11-20$ & 49 & 6 \\
& $21-30$ & 181 & 21 \\
& 31 and above & 592 & 68 \\
\hline Number of Teachers who Have Refugee Students in Their Class & Yes & 812 & 94 \\
& No & 39 & 5 \\
\hline Number of Teachers who Have Refugee Students in Their School & Yes & 852 & 99 \\
& No & 2 & 1 \\
\hline
\end{tabular}

\section{Analysis}

The first aim of this study is to reapply the current scale in a different province, teacher group and time and so as to review the dimensions. Therefore, in this study, RSAS, developed by Sağlam and Kanbur (2017), was re-examined by applying the scale development steps. In order to use RSAS within the scope of our study, CFA was first performed using Mplus (Muthén and Muthén, 2012). However, as reported in the 
findings, since the compliance indexes were below the acceptable values according to the CFA, the CFA was updated again by using the EFA and the CFA again. EFA was performed using SPSS version 22.0 (IBM Corp, 2013). As a result of the factor analysis, it was found that 4 items were displaced between dimensions and it was understood that the related items were more conceptually compatible with the new dimensions by taking expert opinion. As a result of this process, the second aim of the study was to examine the attitudes of teachers towards refugee students in terms of different variables such as being a refugee student in the class and gender. The "communication", "compliance" and "competence" dimensions which were determined based on the factor analysis were calculated as a single variable. These three variables, each dimension of RSAS, were considered as dependent variables, and multivariate analysis of variance (MANOVA) method was used to model teachers' attitudes towards refugee students based on having refugee students in class, gender, teaching years as independent variables. MANOVA were reported with an $F$ value, degrees of freedom $(d f)$, and $p$ value. In addition, a partial eta-squared value was reported for the effect size, especially in comparisons where $p$ value was significant. Effect size is a value that shows how much dependent variables can be explained by independent variables in practice. Cut-off points for this value was determined according to Cohen (1988)'s criteria; 0.01 low, 0.059 medium, and 0.138 high effect size.

\section{FINDINGS}

Among the research questions in this study, a) the revision of the attitude scale towards refugee students is presented under the First Sub-Problem Findings section; b) examining the teachers' attitudes towards refugee students in terms of having refugee students in the class, gender, teaching years variables and giving the general attitude level of the teachers towards refugee students in the light of the revised attitude scale under the Second Sub-Problem is explained under the Findings section.

\section{First Sub-Problem Findings}

To be used in this study, RSAS was used as a data collection tool. Before analyzing the data collected from RSAS, CFA was carried out. The purpose of CFA is to examine the data collected by RSAS according to the construct validity (Büyüköztürk, 2009). In other words, it is aimed to see whether the items of this scale fit the determined dimensions. As given in Figure 1, the items were considered according to the sub-dimensions given by Sağlam and Kanbur (2017) in the original scale. 
.59

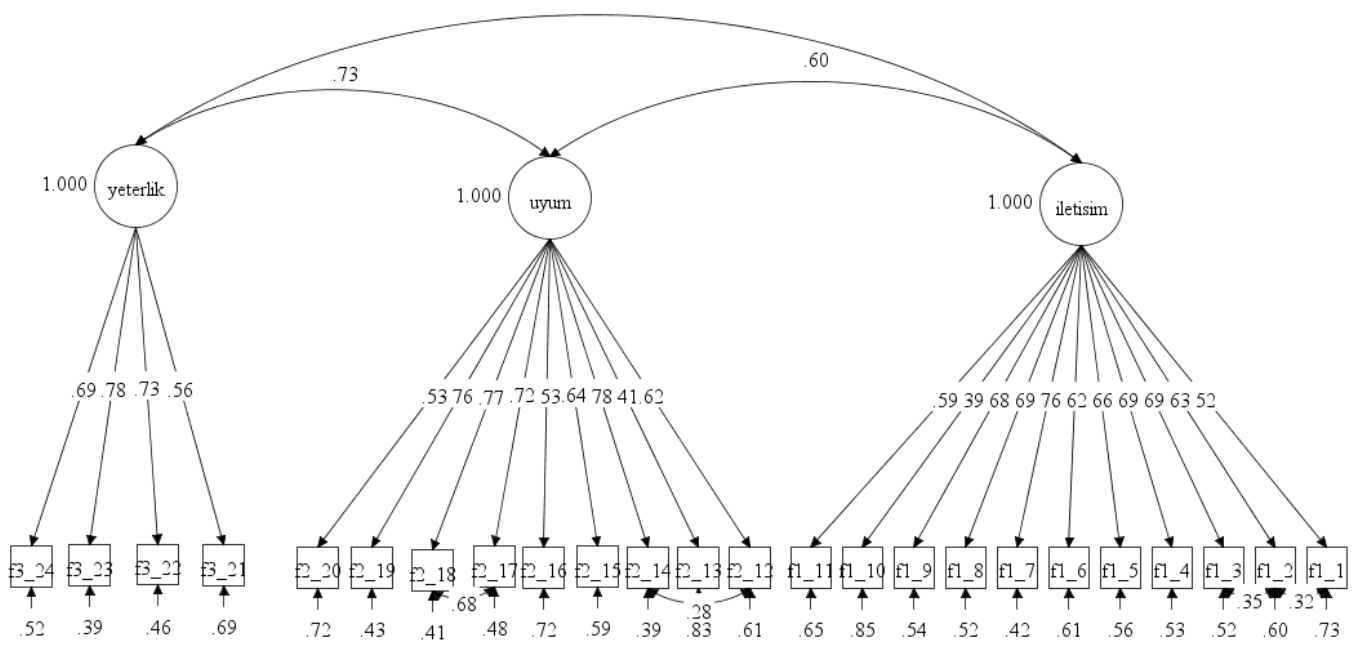

Figure 1. Standardized CFA Diagram

According to CFA results, root mean square error of approximation (RMSEA) was found as .088 and standard root mean square residual value (SRMR) was .089. In addition to these results, Tucker-Lewis index (TLI; Tucker \& Lewis, 1973) and comparative fit index (CFI; Bentler, 1990) were found to be .82 and .84, respectively. Since RMSEA and SRMR values are above .08 and TLI and CFI values are below .90, the original model does not fit well to the data (Bentler \& Hu, 1995; Browne \& Cudeck, 1993; Kline, 2011).

Table 2.

Rotated Component Matrix

\begin{tabular}{cccccc}
\hline \multicolumn{2}{c}{ Communication } & \multicolumn{2}{c}{ Compliance } & \multicolumn{2}{c}{ Competence } \\
Factor_Item & Loading & Factor_Item & Loading & Factor_Item & Loading \\
\hline f1_3 & 0.802 & f2_19 & 0.798 & f3_23 & 0.798 \\
f1_7 & 0.795 & f2_14 & 0.761 & f3_24 & 0.747 \\
f1_8 & 0.740 & f2_15 & 0.731 & f3_22 & 0.734 \\
f1_2 & 0.734 & f2_18 & 0.708 & f2_16 & 0.564 \\
\hline f1_5 & 0.668 & f2_17 & 0.695 & & \\
f1_6 & 0.645 & f1_10 & 0.622 & & \\
f1_9 & 0.635 & f2_12 & 0.574 & & \\
f2_20 & 0.612 & f2_13 & 0.466 & & \\
f3_21 & 0.611 & & & & \\
f1_1 & 0.604 & & & & \\
f1_4 & 0.604 & & & & \\
f1_11 & 0.459 & & & & \\
\hline
\end{tabular}


As a result of the EFA, Kaiser-Meyer-Olkin value, which is a criterion about whether the data can be modeled by factor analytical model, is .92 and Bartlett's sphericity value, which tests the significance of the correlation matrix, was observed as significant $(\mathrm{p}<$ .05). Therefore, EFA results were obtained within the framework of these values. As stated in the original, the items were collected in 3 dimensions and $55.4 \%$ of total variance was explained. Factor loadings of the items at least .40 were preferred as a criterion for an item selection in the dimension.

As shown in Table 2, items 10, 16, 20, and 21 showed high factor loadings of different sizes. Item 10 (Students play with refugee students) was originally written for the "communication" dimension, but is proposed for the "compliance" dimension according to the EFA. Item 16 (Time I allocate to refugee students was sufficient) appears to be in the "competence" dimension, although it was originally written for the "adaptation" dimension. Item 20 (I try to guide refugee students) has been observed in the "communication" dimension, although it was originally written for the "adaptation" dimension. Item 21 (I make it easier for refugee students to adapt to the class) is written in the original scale for the "competence" dimension, although it is in the "communication" dimension. The fact that the CFA values obtained from the original scale was lower than the acceptable values and the subsequent occurrence of 4 items in different sizes according to the results of EFA revealed that these 4 items were redefined in dimensions according to EFA results and CFA was required.

Table 3.

Item-Total Test Correlation and Discrimination Power Analyses

\begin{tabular}{cccccc}
\hline Item No & $r_{j x}$ & $t$ & Item No & $r_{j x}$ & $t$ \\
\hline 1 & $.413^{*}$ & $8.939^{*}$ & 13 & $.372^{*}$ & $9.252^{*}$ \\
2 & $.519^{*}$ & $10.005^{*}$ & 14 & $.683^{*}$ & $19.376^{*}$ \\
3 & $.540^{*}$ & $10.642^{*}$ & 15 & $.525^{*}$ & $13.019^{*}$ \\
4 & $.571^{*}$ & $14.506^{*}$ & 16 & $.491^{*}$ & $13.147^{*}$ \\
5 & $.564^{*}$ & $12.043^{*}$ & 17 & $.624^{*}$ & $16.257^{*}$ \\
6 & $.453^{*}$ & $8.667^{*}$ & 18 & $.682^{*}$ & $18.431^{*}$ \\
7 & $.584^{*}$ & $12.573^{*}$ & 19 & $.636^{*}$ & $15.695^{*}$ \\
8 & $.509^{*}$ & $9.994^{*}$ & 20 & $.630^{*}$ & $14.587^{*}$ \\
9 & $.560^{*}$ & $12.646^{*}$ & 21 & $.683^{*}$ & $17.721^{*}$ \\
10 & $.491^{*}$ & $12.877^{*}$ & 22 & $.558^{*}$ & $15.684^{*}$ \\
11 & $.600^{*}$ & $15.206^{*}$ & 23 & $.589^{*}$ & $15.638^{*}$ \\
12 & $.602^{*}$ & $15.743^{*}$ & 24 & $.518^{*}$ & $13.813^{*}$ \\
\hline
\end{tabular}

Note. ${ }^{*} p<.05 ; r_{j x}$ : Item-total test correlations; $t: t$ test values for item discrimination analyses. 
In Table 3 above, corrected item-total test correlation coefficients and $t$-test values of item discriminative power analysis are presented. Both results provide information on the discriminative power of items. Thus, item-total test correlation coefficient and the discriminative properties of the items are analyzed according to the calculation of the correlation between the scores obtained from each item and the total test. When Table 3 is examined, the item-total test correlation coefficients of all items (except Item 13) are greater than .40, indicating that the items have a high discrimination (Loiacono, Richard, \& Dale, 2002). .372 value of Item 13 is among the acceptable values. According to Classical Test Theory (CTT), in addition to examining item-total test correlation coefficients, the mean difference between the $27 \%$ group of the highest score and the $27 \%$ group of the lowest score was examined by independent samples t test for each scale item. Since $t$ values obtained from all substances were significant $(p<.05)$, it was observed that the item discrimination was sufficient.

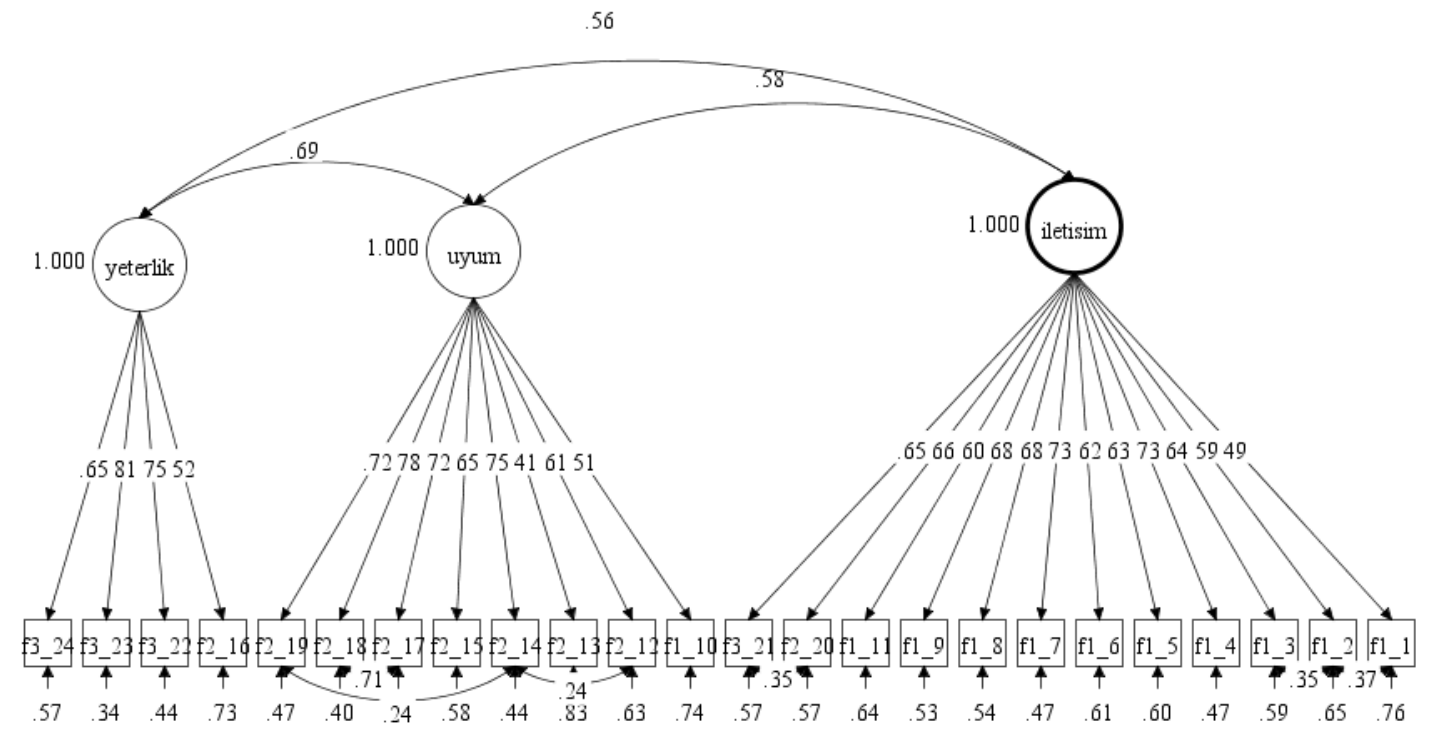

Figure 2. Standardized CFA Diagram (revisied version of RSAS)

In Figure 2 above, the CFA diagram shows the updated version of the RSAS using Mplus. As a result of this analysis, RMSEA value was .065, SRMR value was .062, TLI value was .90 and CFI value was .91. It was observed that these values were within acceptable limits according to the values stated in the literature (Bentler \& Hu, 1995; Browne \& Cudeck, 1993; Kline, 2011). In addition to these analyses, the opinions of academicians and field experts in the field of Measurement and Evaluation on these 4 items were obtained and it was decided to update the RSAS in this way. As a result of this update, reliability values of the whole scale and its dimensions in terms of internal consistency were calculated. In the literature, as an alternative to the Cronbach's alpha coefficient, in some cases it is recommended to calculate the Stratified Alpha coefficient to examine the reliability of the entire scale and its dimensions (Cronbach, Schonemann, \& McKie, 1965; 
Soysal, Gündeğer, \& Doğan, 2018). However, in the study conducted by Soysal, Gündeğer, and Doğan (2018), when the inter-dimensional correlation was at least .50 (eg, the lowest correlation value was .56 between "competence" and "communication" dimensions), there is no significant difference between Cronbach's Alpha and Stratified Alpha values. In order to avoid any differences and to compare the reliability values reported by Sağlam and Kanbur (2017) at the original scale, Cronbach's Alpha values were calculated in this study. In this context, the reliability value of the whole scale was found to be .92 , the communication dimension was .90 , the compliance dimension was .87 and the adequacy dimension was .78. Within the framework of these results, RSAS was updated and scores of three dimensions were calculated by weighting the items for each dimension according to the degree of explanation.

\section{Second Sub-Problem Findings}

In this study, firstly, total scale and dimension score averages were calculated to obtain information about the group in general. When Table 4 is examined, according to the data collected from the scale, it is seen that the average attitude of teachers towards refugee students is $\bar{X}=3.07$, while the attitude of teachers who have refugee students in the class is $\bar{X}=3.08$, the attitude of teachers who do not have refugee students in the class is low, $\bar{X}=2.98$. In terms of dimensions, the lowest level of attitude was observed in the competency dimension for teachers who do not have refugee students in the class $(\bar{X}=$ 2.56); one of the highest average attitude of teachers is the communication dimension $(\bar{X}$ $=3.49$ ). Considering that the highest score is 4 point for each item of the scale, it can be said that the general attitudes of teachers are "very good", that is, "I mostly agree."

\section{Table 4.}

The Average Teacher Attitudes towards Refugee Students

\begin{tabular}{ccccc}
\hline & Total Scale & Communication & Adaptation & Competence \\
\cline { 2 - 5 } General & 3.07 & 3.49 & 2.73 & 2.51 \\
RSC & 3.08 & 3.49 & 2.74 & 2.51 \\
Non-RSC & 2.98 & 3.43 & 2.56 & 2.49 \\
\hline
\end{tabular}

Note: $\mathrm{RSC}=$ teachers with refugee students in the class

In the analysis using MANOVA, "communication", "adaptation," and "competence" dimensions are used as dependent variables, teaching years, gender, area of expertise, liking field, and whether or not there are refugee students in class and school as independent variables. In this study, teachers' attitudes towards refugee students were examined according to each dimension of this scale. The assumptions necessary for MANOVA analysis were examined. First, the outliers were tested with the Mahalanobis distance method, and four data whose Mahalanobis value $(16.80,20.15,32.79$, and 61.32) were greater than the critical value $16.27(d f=3)$ were deleted. In the second 
step, the scatter plot for the linear relationship between the dependent variables for each independent variable group was examined and it was observed that the data provided this assumption. In the third step, the multivariate normality assumption was met because the dimensions of RSAS was obtained by standardizing the items corresponding to the related dimensions by the regression method. Finally, by looking at the correlation between the dependent variables, the correlation values were found as .486 (communication and competence), .489 (communication and compliance), and .589 (competence and compliance). Thus, multicollinearity assumption was also met. According to the findings, it was concluded that the data used in the study satified the assumptions for MANOVA.

According to the results of the analysis, the variables of the area of expertise, whether or not the teachers like their field, the presence of refugee students at school did not show any difference in terms of teachers' attitudes towards refugee students (e.g., $F(3,315)=$ $1.95, p>.05)$. However, the gender of teachers, the number of teaching years, and having refugee students in their class showed differences on the dimensions of "communication", "adaptation," and "competence (Table 5).

It has been concluded that the attitudes of the female teachers towards the refugee students who have not completed 5 years in the teaching are higher than the male teachers in terms of "communication" $\left(F(1,317)=4.42, p<.05\right.$; partial $\left.\eta^{2}=.014\right)$. The partial eta-square value $\left(\eta^{2}=.014\right)$ was low according to Cohen (1988)'s criteria and $1.4 \%$ of the attitudes of female teachers towards refugee students who had not completed 5 years in teaching were explained. When this result is investigated mathematically, it is observed that female teachers' attitudes towards refugee students in terms of "communication" are higher than .25 points. When "adaptation" $(F(1,317)=$ $1.74, p>.05)$ and "competence" $(F(1,317)=.002, p>.05)$ dimensions were examined, no difference was observed between felame and male teachers who are novice in the profession.

Female and male teachers who have been teaching for at least 6 and at most 11 years did not show different attitudes towards refugee students in "communication" $(F(1,210)=$ $.717, p>.05)$ and "competence" $(F(1,210)=.301, p>.05)$ dimensions, although female teachers showed higher attitudes towards refugee students than male teachers in "adaptation" dimension $\left(F(1,317)=5.98, p<.05\right.$; partial $\left.\eta^{2}=.028\right)$. In other words, it was observed that the attitudes of female teachers towards refugee students showed "adaptation" .33 points higher than male teachers. The effect size is low based on the partial eta-square value $\left(\eta^{2}=.028\right)$. 
Table 5.

MANOVA Results for Teacher Attitudes towards Refugee Students based on Gender and Teaching Years

\begin{tabular}{|c|c|c|c|c|c|c|}
\hline Teaching Years & $\begin{array}{l}\text { Dependent } \\
\text { Variables }\end{array}$ & Parameter & $B$ & $S E$ & $t$ & $p$ \\
\hline \multirow{6}{*}{$0-5$ years } & Communication & Intercept & -0.24 & 0.098 & -2.471 & .014 \\
\hline & & Women & 0.25 & 0.117 & 2.102 & .036 \\
\hline & Adaptation & Intercept & -0.21 & 0.102 & -2.003 & .046 \\
\hline & & Women & 0.16 & 0.123 & 1.32 & .188 \\
\hline & Competence & Intercept & -0.04 & 0.101 & -0.392 & .695 \\
\hline & & Women & 0.01 & 0.121 & 0.049 & .961 \\
\hline \multirow{6}{*}{$6-11$ years } & Communication & Intercept & 0.06 & 0.107 & 0.523 & .602 \\
\hline & & Women & -0.12 & 0.143 & -0.847 & .398 \\
\hline & Adaptation & Intercept & -0.23 & 0.102 & -2.249 & .026 \\
\hline & & Women & 0.33 & 0.136 & 2.445 & .015 \\
\hline & Competence & Intercept & -0.08 & 0.106 & -0.751 & .454 \\
\hline & & Women & 0.08 & 0.141 & 0.549 & .584 \\
\hline \multirow{6}{*}{$\begin{array}{l}12 \text { years and } \\
\text { above }\end{array}$} & \multirow{2}{*}{ Communication } & Intercept & 0.19 & 0.086 & 2.194 & .029 \\
\hline & & Women & -0.28 & 0.137 & -2.017 & .045 \\
\hline & \multirow{2}{*}{ Adaptation } & Intercept & 0.14 & 0.085 & 1.657 & .099 \\
\hline & & Women & 0.13 & 0.135 & 0.979 & .329 \\
\hline & \multirow{2}{*}{ Competence } & Intercept & 0.19 & 0.086 & 2.242 & .026 \\
\hline & & Women & -0.28 & 0.137 & -2.026 & .044 \\
\hline
\end{tabular}

These results have been observed in the opposite direction for teachers who have been teaching for many years (12 years and above) $(F(3,220)=5.94, p<.05$; Wilk's $\Lambda=.925$, partial $\eta^{2}=.075$ ). For example, male teachers have higher attitudes in terms of "communication" and "competence" towards refugee students than female teachers. According to Cohen (1988)'s criteria, this difference has an effect size above the medium level and $7.5 \%$ of the total variance is explained. Mathematically, male teachers' attitudes towards refugee students in both "communication" and "competence" dimensions were .28 points higher than female teachers $(F(1,222)=4.1, p<.05$; partial $\eta^{2}=.045$ ). The effect size is close to moderate and $4.5 \%$ of the total variance is 
explained. However, there was no difference in the "adaptation" dimension $(F(1,222)=$ $.96, p>.05)$.

Table 6.

MANOVA Results for Teacher Attitudes towards Refugee Students based on Teachers who have Refugee Students in Class and Years of Teaching

\begin{tabular}{cccccc}
\hline $\begin{array}{c}\text { Dependent } \\
\text { Variable }\end{array}$ & Parameter & $B$ & $S E$ & $t$ & $p$ \\
\hline Communication & Intercept & -0.84 & 0.409 & -2.063 & 0.040 \\
& RSC & 0.95 & 0.415 & 2.300 & 0.022 \\
\hline Adaptation & Intercept & -0.86 & 0.400 & -2.145 & 0.033 \\
& RSC & 1.07 & 0.406 & 2.630 & 0.009 \\
\hline Competence & Intercept & -0.56 & 0.412 & -1.365 & 0.174 \\
& RSC & 0.66 & 0.417 & 1.578 & 0.116 \\
\hline
\end{tabular}

Note: $\mathrm{RSC}=$ teachers with refugee students in class; teaching for 12 years and above.

In addition to these results, it was examined whether the attitudes of teachers towards refugee students differed on the variables of "communication", "adaptation" and "competence" according to the presence of refugee students in class and years of teaching. According to the results, there was no difference between teachers who have been teaching for less than 12 years and who have refugee students in class and those who have not. For example, there was no significant difference in attitudes towards refugee students among teachers teaching less than 5 years $(F(3,315)=511, p>.05)$. Table 6 shows the significant difference observed in teachers who have been teaching for 12 years or above $\left(F(3,219)=511, p<.05\right.$; Wilk's $\Lambda=.965$, partial $\left.\eta^{2}=.035\right)$. Accordingly, it was observed that teachers who had refugee students in class had higher "communication" $\left(F(1,221)=5.29, p<.05\right.$; partial $\left.\eta^{2}=.023\right)$ and "adaptation" $(F(1$, 221) $=6.92, p<.05$; partial $\eta^{2}=.030$ ) attitudes towards refugee students than teachers without refugee students in class. Teachers with refugee students in class were .95 points higher in terms of "communication" and 1.07 points higher in terms of "adaptation". In addition, it was observed that the effect sizes were close to the medium level.

\section{RESULTS, DICSUSSION AND SUGGESTIONS}

\section{Results and Discussion}

The goal of this study is to re-examine an existing attitude scale towards refugee students and to examine the attitudes of teachers towards refugee students in terms of having a refugee student in the class, gender and teaching year variables. In addition, in 
the light of the revised attitude scale, it was aimed to reveal the general attitude level of the participant teachers towards refugees. The results of these findings are discussed below in the relevant paragraphs.

The scale developed by Sağlam and Kanbur (2017) was observed to have items which changed their places in three dimensions in this study, it was accepted that the updated form of the scale was appropriate. RSAS, developed by Sağlam and Kanbur (2017), was subjected to CFA and EFA analyzes and the items 10, 16, 20 and 21 gave more meaningful results in different dimensions. For example, the item 10 (students play with refugee students) was originally written for the "communication" dimension; however, it was concluded that it would be more appropriate for the "adaptation" dimension when statistical analysis and the views of the academicians in the field of Measurement and Evaluation were examined.

In this study, in order to reveal the general attitude level of the teachers towards refugee students, total scale points and averages were examined according to the 5-point Likert data collected from the teachers. In the study, it was generally seen that the teachers' attitudes towards refugee students in terms of general points and dimensions were at the level of very good and good. As a matter of fact, it was determined that the teachers' attitudes towards Syrian refugee students were generally "very good"; that is, the teachers generally responded to the statements in the scale with "mostly agree". Similarly, Sağlam and Kanbur (2017) found that general attitudes of class teachers towards refugee students were high. In another study conducted by İzmir Konak RAM (2018), it was observed that the attitude towards refugee students was positively good. In the study of Köse, Bülbül and Uluman (2019), the average of the attitude points of the teachers towards refugee students was found to be positively high (71 out of 96). In this respect, the results of this study are consistent with the related literature. In addition, teachers' attitudes towards refugees from the same scale in three different provinces are generally ticked with "mostly agree", which can be exaplained with Turkey's having a multicultural structure, its experience of internal migration and its openness to diversity and differences. Supporting this, in the study of Konak RAM (2018), the teachers views were taken, and the highest attitude points (totally agree) were found to be from teachers in disadvantaged schools. In the past of these schools, there were already many migrants before arrival of Syrain refugees and they had multicultural background. According to Yazıcl, Başol, and Toprak (2009, p.239), Turkish teachers generally have positive attitudes towards multicultural education.

According to the results of the analysis, the general attitude points of teachers with no refugee students in the class in this study were found to be lower than those of teachers with refugee students in their class. Also, there was found some significant differences in terms of "communication", "adaptation" and "efficiency" dimensions according to the gender of the teachers, the year they spent in the profession (teaching year) and the presence of refugee students in class. 
In this study, it was concluded that the attitudes of female teachers towards refugee students, who were in the 5 years of their duties, were significantly higher in terms of "communication" than those of male teachers. It was found that female teachers who were teaching for 6-11 years had higher "adaptation" for refugee students than male teachers. In the study of Sağlam and Kanbur (2017), it was found that the attitudes towards refugee students did not exhibit a significant difference in "communication" and "adaptation" dimensions and total scale points according to their gender; but "efficiency" dimension differed significantly in favor of male teachers. In the study conducted by Köse, Bülbül, and Uluman (2019) on teacher attitudes towards refugee students, there was found no significant difference according to gender variable. In another study, a significant difference was found for teachers' social acceptance levels of the Syrian students under temporary protection according to their gender; that is, male teachers' social acceptance levels are higher than female teachers (Konak RAM, 2018). When the gender is analyzed, it is observed that there are different results in related studies.

Among teachers who were teaching for long years (12 years and over), male teachers were found to have higher awareness of "communication" and "efficiency" than female teachers. Sağlam and Kanbur (2017) found a significant difference in "efficiency" dimension in favor of male teachers and stated that male teachers considered themselves more efficient for refugee students than female teachers. There are different results in terms of both studies. In this study, the results are examined in terms of gender and teaching year variables, while in the other study gender is examined without teaching year variable.

In addition to these results, there was observed a significant difference among teachers who were teaching for 12 years or more upon the analysises conducted according to presence of refugee students and the time/years spent in teaching. Accordingly, "communication" and "adaptation" attitudes of teachers towards refugee students with at least 12 years of experience teaching were higher than those of teachers with no refugee students in class. In this respect, assuming the fact that experienced teachers have refugee students in class, it can be said that they have experienced communication and adaptation process in a more qualified way as required by inclusive education. In the study of Sağlam and Kanbur (2017), it was observed that the attitudes of the participating teachers towards refugee students did not differ in terms of "communication" while "adaptation" and "efficiency" dimensions and total scale point differed significantly in favor of teachers with refugee students in their class. When the results were examined in terms of two studies, though similar results were found, two studies were conducted on different samples and regional factors may have led to differences in the study results. Köse, Bülbül, and Uluman (2019) found that the attitudes of teachers with refugee students in their classs and those of teachers with no refugee students in their class did not differ, they added that this may be caused by the fact that teachers see and recognize refugee students from other class even if they do not have refugee students in their class. 
In general, it can be said that the teachers in the study displayed positive attitudes towards refugee students, as stated in other studies in the field, but when the attitudes of teachers were examined in terms of teaching experience/year, gender, and the presence of refugee students in the class, similar and different results were found in the studies (see, Konak RAM, 2018; Köse, Bülbül, \& Uluman, 2019; Sağlam \& Kanbur, 2017) The source of these differences can be multifaceted. These results may be based on different reasons scuh as having samples from different regions, the proportion of teachers in different regions facing refugee student-based problems at different degrees, the difference of school-family-environment-based factors, and so on.

\section{Suggestions}

As a result of the study, it was found that the attitudes of the teachers towards the Syrian refugee students were positive. In the partnership between MoNE and related institutions, applications based on diversity management and inclusive education can be increased to higher levels in schools.

Additional attention can be given to the education of values in schools with Syrian refugee students, which emphasizes that being from different languages and nationalities and learning from our differences is actually a wealth of humanity in schools.

There are many studies on qualitative aspect of education for Syrian refugees in Turkey which accomadates the largest numbers of Syrain refugees while there a few studies on scale development for teacher attitudes towards these refugees. There is a more need for quantitative studies in Turkey in order to demonstrate the general attitud es towards refugees. Holistic studies on teachers, parents and students can be done in regard to attitudes for refugees.

In the study, it was seen that the "communication" and "adaptation" attitudes of the young female teachers were generally high compared to those of male participants, whereas the male teachers who worked for long years (12 years and over) had higher attitudes in "communication" and "efficiency" dimensions than the female teachers. In line with the results of this study, other studies can be supported by qualitative techniques according to the gender and teaching years and the reason for these differences can be explained.

It was determined that the "communication" and "adaptation" attitudes of the experienced teachers towards the refugee students were higher in the classs than those of teachers with no-refugee students in the class. The reasons for not having similar results for teachers with less experienced or less years of working experience can be supported by qualitative studies in terms of years of experience. In general, having different outcomes in studies can be a step for policymakers to engage in deeper studies with high impact impacts on inclusive education and management of differences. 


\section{References}

Alpaydın, Y. (2017). An analysis of educational policies for school-aged Syrian refugees in Turkey. Journal of Education and Training Studies, 5(9), 36-44.

Bentler, P. M. (1990). Comparative fit indexes in structural models. Psychological Bulletin, 107, 238-246.

Bentler, P. M., \& Hu, P. (1995). EQS: Structural equations program manual. Los Angeles, CA: BMPD Statistical Software.

Birleşmiş Milletler Mültecilerin Hukuki Statüsüne İlişkin 1951 Sözleşmesi. (1951). Erişim Adresi: https://www.tbmm.gov.tr/tutanaklar/TUTANAK/KM /d00/c002/km 00002024ss0053. pdf

Browne, M. W., \& Cudeck, R. (1993). Alternative ways of assessing model fit. In K. A. Bollen ve J. S. Long (Eds.). Testing Structural Equation Models (pp. 136-162). Thousand Oaks, CA: Sage.

Büyüköztürk, Ş. (2002). Faktör analizi: Temel kavramlar ve ölçek geliştirmede kullanımı. Kuram ve Uygulamada Ĕ̆itim Yönetimi Dergisi, 8(32), 470-483.

Büyüköztürk, Ș. (2009). Sosyal bilimler için veri analizi el kitabı. Ankara: Pegem A Yayıncılık.

Cohen, J. (1988). Statistical power analysis for the behavioral sciences (2nd ed.). Hillsdale, NJ Lawrence Erlbaum Associates, Publishers.

Cronbach, L. J., Schonemann, P., \& McKie, D. (1965). Alpha coefficients for stratified-paralel tests. Educational and Psychological Measurement, 25, 291-312.

Çatalbaş, G. K., \& Yarar, Ö. (2015). Türkiye'de bölgeler arası iç göçü etkileyen faktörlerin panel veri analizi ile belirlenmesi. The Journal of Operations Research, Statics, Econometrics and Management Information Systems, 3(1), 99-117.

Çoşkun, İ., \& Emin, M. N. (2016). Türkiye'deki Suriyelilerin eğitimde yol haritası. Fırsatlar ve zorluklar. SETA Siyaset, Ekonomi ve Toplum Araştırmaları Vakfı: İstanbul. Erişim adresi: http://file.setav.org/Files/Pdf/20160906135243_turkiyedeki-suriyelilerin-egitimindeyol-haritasi-pdf.pdf

Düşkün, Y. (2016). Türkiye'de ortaöğretimde kapsayıcı eğitim durum analizi. Eğitim Reformu Girişimi. İstanbul: İmak Ofset, 18.

Dryden-Peterson, S. (2011) Refugee education: A global review. Retrieved from https://www.unhcr.org/hu/wpcontent/uploads/sites/21/2016/12/Dryden_Refugee_Edu cation_Global-Rvw.pdf

IBM Corp. (2013). IBM SPSS statistics for windows (Version 22.0). Armonk, NY: IBM Corp.

Karasar, N. (2005). Bilimsel araştırma yöntemi. Ankara: Nobel Yayınevi.

Kardeş, S., \& Akman, B. (2018). Suriyeli mültecilerin eğitimine yönelik öğretmen görüssleri. Illköğretim Online, 17(3), 1224-1237.

Kline, R. B. (2011). Principles and practice of structural equation modeling. Guilford press.

Kılcan, B., Çepni, O., \& Kılınç, A. Ç. (2017). Mülteci öğrencilere yönelik tutum ölçeğinin geliştirilmesi. Journal of Human Sciences, 14(2), 1045-1057.

Konak RAM, (2018). İzmir ili Konak ilçesi ilkokullarındaki öğretmen ve öğrencilerin, Suriyeli öğrencilere yönelik sosyal kabul düzeylerinin tespit edilmesi. Erişim adresi: http://konakram.meb.k12.tr/meb_iys_dosyalar/35/01/164246/dosyalar/2018_10/0811 5626_YZMYR_YLY_KONAK_YLYESY_04.10.2018.pdf 
Köse, N., Bülbül, Ö., \& Uluman, M . (2019). Sınıf öğretmenlerinin mülteci öğrencilere yönelik tutumlarının çeşitli değişkenler açısından incelenmesi. Journal of Continuous Vocational Education and Training, 2(1), 16-29.

Loiacono, E. T., Richard, T. W., \& Dale, L. G. (2002). WebQual ${ }^{\mathrm{TM}}$ : A measure of website quality. In AMA Winter Conference. Austin, TX.

Miserez-Willday, D. (Ed.). (1988). Refugees-the trauma of exile: The humanitarian role of Red Cross and Red Crescent. Martinus Nijhoff Publishers.

Muthén, L. K., \& Muthén, B. O. (2012). Mplus user's guide (Seventh Edition). Los Angeles, CA: Muthén \& Muthén.

Nunnally, J. C., \& Bernstein, I. H. (1978). Psychometric theory. NewYork: McGraw-Hill.

Öğretmen Yetiştirme Genel Müdürlüğü. (2018). Kapsayıcı eğitim projesi. Retrieved from http://oygm.meb.gov.tr/www/kapsayici-egitim-projesi-inclusive-education/icerik/679

Özcan, A. (2018). Çokkültürlülük bağlamında Türkiye'nin Suriyeli öğrencilere yönelik eğitim politikası. PESA Uluslararası Sosyal Araştırmalar Dergisi, 4(1), 17-29.

Rennie, K. M. (1997, January). Exploratory and confirmatory rotation strategies in exploratory factor analysis. Paper presented at the annual meeting of the Southwest Educational Research Association, Austin, USA.

Sağlam, H. İ., \& İlksen Kanbur, N. (2017). Sınıf öğretmenlerinin mülteci öğrencilere yönelik tutumlarının çeşitli değişkenler açısından incelenmesi. Sakarya University Journal of Education, 7(2), 310-323.

Soysal, S., Gündeğer, C., \& Doğan, N. (2018, Eylül). Çok boyutlu test yapılarında güvenirliğin incelenmesi. 6. Uluslararası Eğitimde ve Psikolojide Ölçme ve Değerlendirme Kongresinde sunulan bildiri. Prizren, Kosova. Erişim adresi: $\underline{\mathrm{http}: / / \mathrm{c}-}$ meep2018.hku.edu.tr/Content/files/CMEEP2018-Proceedings.pdf

Taylor, S., \& Sidhu, R. K. (2012). Supporting refugee students in schools: What constitutes inclusive education? International Journal of Inclusive Education, 16(1), 39-56.

Tucker, L. R., \& Lewis, C. (1973). A reliability coefficient for maximum likelihood factor analysis. Psychometrika, 38, 1-10.

Yazıcı, S., Başol, G., \& Toprak, G. (2009). Öğretmenlerin çok kültürlü eğitim tutumları: Bir güvenirlik ve geçerlik çalışması. Hacettepe Üniversitesi Eğitim Fakültesi Dergisi, 37, 229242.

Yavuz, Ö., \& Mızrak, S. (2016). Acil durumlarda okul çağındaki çocukların eğitimi: Türkiye'deki Suriyeli mülteciler örneği. Göç Dergisi, 3(2), 175-199. 